\title{
Faktor Prognosis Derajat Keparahan Infeksi Dengue
}

Arie Yulianto, Ida Safitri Laksono, Mohammad Juffrie

Bagian Ilmu Kesehatan Anak Fakultas Kedokteran Universitas Gadjah Mada/RSUP Dr. Sardjito, Yogyakarta

Latar belakang. Infeksi virus dengue (IVD) bersifat akut dan dinamis, perjalanan klinisnya terkadang sulit diprediksi sehingga berakibat keterlambatan pengelolaan. Maka perlu diteliti parameter klinis dan laboratoris di fase kritis / defervescence untuk memprediksi derajat keparahan infeksi dengue.

Tujuan. Mengetahui parameter klinis dan laboratoris sebagai faktor prognosis derajat keparahan infeksi dengue.

Metode. Penelitian kohort retrospektif, menggunakan data rekam medik pasien anak IVD yang dirawat di RSUP Dr. Sardjito Yogyakarta dari Januari 2014 - Desember 2015. Faktor prognosis yang diteliti adalah usia, jenis kelamin, tanda klinis warning signs, serta laboratorium. Kriteria eksklusi adalah adanya penyakit hematologi dan penyakit jantung bawaan. Analisis statistik dengan metode regresi logistik.

Hasil. Di antara 188 pasien yang memenuhi kriteria penelitian, 56 (30\%) didiagnosis demam dengue (DD), 58 (31\%) demam berdarah dengue derajat $1-2$ (DBD), dan 74 (39\%) sindrom syok dengue (SSD). Analisis multivariat menunjukkan nyeri perut (OR 5,06, IK 95\%: 1,72;14,87), hepatomegali >2 cm (OR 7,57, IK 95\%: 2,86;20,02), hematokrit >45\% (OR 5,10, IK 95\%: 1,74;14,95), dan trombosit $\leq 50.000 / \mathrm{uL}$ (OR 17,80, IK 95\%: 3,78;83,80) merupakan faktor prognosis independen derajat keparahan infeksi dengue Kesimpulan. Nyeri perut, hepatomegali $>2 \mathrm{~cm}$, hematokrit $>45 \%$ dan trombosit $\leq 50.000 / \mathrm{uL}$ di fase defervescence merupakan faktor prognosis independen terjadinya infeksi dengue yang lebih berat (DBD dan SSD). Sari Pediatri 2016;18(3):198-203

Kata kunci: infeksi dengue, warning signs, faktor prognosis

\section{Prognostic Factors for Dengue Infection Severity}

Arie Yulianto, Ida Safitri Laksono, Mohammad Juffrie

Background. Dengue infection is an acute and dynamic disease. Progression of disease around the time of fever defervescence is essential to predict the clinical outcomes. The search for prognostic factors at the time of defervescence continues.

Objective. To explore clinical findings and routine laboratory parameters, that could be used as prognostic factors for dengue infection severity.

Methods. We conducted a retrospective cohort study in children who were admitted to Dr. Sardjito Hospital with dengue infection between 2014 and 2015. Patient characteristics of interest included sex, age, presence of WHO warning signs and laboratory parameters. Hematologic and congenital heart diseases were excluded from the study. The prognostic factors for dengue severity were analyzed by a multivariate logistic regression.

Results. Of 188 eligible children, 56 (30\%) were classified as dengue fever (DF), 58 (31\%) with dengue hemorrhagic fever grade I - II (DHF), and 74 (39\%) with dengue shock syndrome (DSS). Under multivariate logistic regression analysis, characteristics that increased the risk of DHF and DSS were; abdominal pain (OR, 5.06; 95\% CI, 1.72-14.87), hepatomegaly >2 cm (OR, 7.57; 95\% CI, 2.86-20.02), hematocrit $>45 \%(\mathrm{OR}, 5.10 ; 95 \% \mathrm{CI}, 1.74-14.95)$, and platelet count $\leq 50.000 / \mathrm{uL}(\mathrm{OR}, 17.80 ; 95 \% \mathrm{CI}, 3.78-83.80)$. Conclusion. Presence of abdominal pain, hepatomegaly $>2 \mathrm{~cm}$, hematocrit $>45 \%$ and platelet count $\leq 50.000 / \mathrm{uL}$ at the time of defervescence could be used as independent prognostic factors for dengue infection severity. Sari Pediatri 2016;18(3):198-203

Keywords: dengue infection, warning signs, prognostic factors

Alamat korespondensi: Dr. Arie Yulianto. Bagian Ilmu Kesehatan Anak, Fakultas Kedokteran Universitas Gadjah Mada/ RSUP Dr. Sardjito, Jl. Kesehatan No.1 Sekip Yogyakarta 55284, Indonesia. E-mail: drarieyulianto@gmail.com 
I nfeksi virus dengue merupakan masalah kesehatan utama pada anak, khususnya di negara berkembang. Dalam 50 tahun terakhir, insiden infeksi virus dengue meningkat 30 kali lipat, diperkirakan 50 juta orang terinfeksi setiap tahun dan 2,5 milyar orang tinggal di daerah endemis. Berdasarkan jumlah kasus demam berdarah dengue (DBD), Indonesia menempati kasus tertinggi di kawasan Asia Tenggara. ${ }^{1}$ Infeksi virus dengue telah menyebar di 33 provinsi dan 436 kabupaten / kota dari 497 kabupaten / kota di Indonesia. Data Kementrian Kesehatan RI menunjukkan kenaikan signifikan angka kesakitan dari 0,05 per 100000 pada tahun 1968 menjadi 39,8 per 100000 penduduk tahun 2014, dengan angka kematian (case fatality rate) 0,90\%. Kejadian epidemik tertinggi dilaporkan terjadi pada tahun 2010, yaitu 86 per 100000 kasus. ${ }^{2}$ Lima provinsi dengan angka kesakitan tertinggi adalah Bali, DKI Jakarta, Kalimantan Timur, Sulawesi Tengah, dan DI Yogyakarta. Data Kemkes tahun 2015 menunjukkan 3420 kasus di DIY, dengan CFR 1\%. Di RSUP Dr Sardjito Yogyakarta pada tahun 2014, angka kematian pasien infeksi dengue 3,1\%, menurun menjadi 2,6\% pada tahun 2015. Kesulitan memprediksi perjalanan klinis dari infeksi virus dengue, terutama memprediksi kondisi awal syok, seringkali menjadi penyebab keterlambatan pengelolaan sehingga mengakibatkan komplikasi berupa perdarahan, disfungsi berbagai organ sebelum pasien tiba di rumah sakit rujukan. ${ }^{3}$

Infeksi virus dengue bersifat akut, dinamis dengan spektrum manifestasi klinis yang bervariasi mulai dari paling ringan (undifferentiated febrile illness) sampai dengan dengue berat. Pada awal perjalanan penyakit seringkali sulit untuk membedakan infeksi ringan dari infeksi berat. Pada dasarnya tidak ada penanganan spesifik untuk infeksi virus dengue, tetapi deteksi dini dan penanganan yang cepat dan tepat dapat menurunkan mortalitas. Pedoman WHO tahun 2009 dan 2011 merekomendasikan penggunaan kriteria tanda bahaya (warning signs) sebagai salah satu indikator untuk memonitor tingkat keparahan penyakit. Kriteria tersebut meliputi nyeri perut, muntah berkepanjangan, akumulasi cairan di ruang interstitial, perdarahan mukosa, letargi, pembesaran hati $>2 \mathrm{~cm}$, peningkatan hematokrit seiring dengan penurunan jumlah trombosit secara cepat. ${ }^{4}$ Namun, penelitian di Thailand menunjukkan penggunaan warning signs juga memiliki keterbatasan, penerapan yang terlalu dini terutama di awal perjalanan penyakit dapat menyebabkan over-admission., ${ }^{5,6}$

Penelitian ini bertujuan untuk mengetahui parameter klinis dan laboratoris di fase kritis I defervescence sebagai faktor prognosis derajat keparahan infeksi dengue. Indikator ini diharapkan dapat bermanfaat dalam triase untuk memfasilitasi penanganan dan mengidentifikasi pasien yang memiliki risiko terjadinya kasus dengue berat.

\section{Metode}

Penelitian dilakukan dengan desain kohort retrospektif pada anak usia 0-18 tahun yang dirawat di RSUP Dr. Sardjito Yogyakarta dengan infeksi dengue menurut pedoman WHO 2011 sejak Januari 2014 sampai Desember 2015. Derajat keparahan infeksi dengue diklasifikasikan sebagai demam dengue (DD), demam berdarah dengue derajat 1 dan 2 (DBD), serta demam berdarah dengue derajat 3 dan 4 sebagai sindrom syok dengue (SSD). Data dikumpulkan saat fase defervescence dari rekam medis pasien menggunakan kuesioner, yang meliputi data demografi (usia, jenis kelamin, status gizi, hari sakit saat masuk rumah sakit), gejala klinis (nyeri kepala, nyeri otot), dan tanda klinis warning signs (nyeri perut, hepatomegali $>2 \mathrm{~cm}$, tanda kebocoran plasma, episode perdarahan, letargi / akral dingin), hasil pemeriksaan laboratorium (nilai hematokrit, angka trombosit, leukosit, hasil serologi dengue) serta luaran penyakit (hidup atau mati). Kriteria eksklusi jika ditemukan penyakit kronis dan penyakit hematologi.

Analisis multivariat dengan metode regresi logistik digunakan untuk mengetahui faktor yang memengaruhi derajat keparahan infeksi dengue.

\section{Hasil}

Didapat 658 anak usia 0-18 tahun dengan infeksi dengue dirawat di RSUP Dr. Sardjito selama periode penelitian. Dua ratus anak dipilih secara random sampling, 8 anak dieksklusi karena data yang tidak lengkap, 3 anak dengan penyakit jantung bawaan sianotik dan 1 anak dengan anemia berat. Di antara 188 anak yang memenuhi kriteria, DD 56 (30\%), DBD derajat I-II 58 (31\%) dan SSD 74 (39\%). Angka kematian infeksi dengue 6/188 (3\%). Karakteristik subyek penelitian tertera pada Tabel 1 . Terdapat $40 \%$ 
anak berusia 0-5 tahun dengan proposi laki-laki : perempuan 1,07: 1. Enampuluh sembilan persen anak dengan gizi baik dan $2 \%$ dengan gizi buruk. Anak masuk rumah sakit pada saat fase defervescence 69\%, yaitu hari sakit ke-4 dan ke-5.

Karakteristik klinis dan laboratoris yang membedakan di antara keparahan infeksi dengue adalah nyeri perut, hepatomegali $>2 \mathrm{~cm}$, kebocoran plasma, episode perdarahan (petekie, perdarahan saluran cerna), letargi/akral dingin, nilai hematokrit, dan angka trombosit terendah selama fase defervescence (Tabel 2 dan 3). Faktor yang meningkatkan risiko terjadinya DBD adalah nyeri perut (OR 4,7), hepatomegali $>2$ $\mathrm{cm}$ (OR 6,1), petekie (OR 2,6), kebocoran plasma (OR 400,7), hematokrit $>45 \%$ (OR 4,1), dan angka trombosit $\leq 50.000 / \mathrm{uL}$ (OR 11,2).

Faktor yang meningkatkan risiko terjadinya SSD adalah nyeri perut $(\mathrm{OR} 9,3)$, hepatomegali $>2 \mathrm{~cm}(\mathrm{OR}$ 30), petekie (OR 3,1), letargi/akral dingin (OR 139,5), kebocoran plasma (OR 1.980), hematokrit $>45 \%$ (OR $14,5)$, dan angka trombosit $\leq 50.000 / \mathrm{uL}(\mathrm{OR} 37,5)$ (Tabel 4). Hasil analisis multivariat dengan metode regresi logistik didapatkan nyeri perut (OR 5,06, IK 95\%: 1,72;14,87), hepatomegali >2 cm (OR 7,57, IK
Tabel 1. Karakteristik dasar

\begin{tabular}{lc}
\hline Karakteristik & $\mathrm{n}=188$ \\
\hline Jenis kelamin, laki-laki, n (\%) & $97(52)$ \\
Usia (\%, tahun) & \\
$0-5$ & $75(40)$ \\
$5-10$ & $47(25)$ \\
$>10$ & $66(35)$ \\
Status gizi, n (\%) & \\
Baik & $129(69)$ \\
Kurang & $32(17)$ \\
Buruk & $5(2)$ \\
Lebih & $11(6)$ \\
Obese & $11(6)$ \\
Hari masuk rumah sakit, n (\%) & \\
4 & $60(32)$ \\
5 & $70(37)$ \\
6 & $39(21)$ \\
Luaran, n (\%) & $182(97)$ \\
Hidup & $6(3)$ \\
Meninggal & \\
\hline
\end{tabular}

Tabel 2. Profil gejala klinis

\begin{tabular}{|c|c|c|c|c|}
\hline Profil klinis & $\begin{array}{c}\text { DD } \\
56(30 \%) \\
\end{array}$ & $\begin{array}{c}\text { DBD } \\
58(31 \%) \\
\end{array}$ & $\begin{array}{c}\text { SSD } \\
74(39 \%) \\
\end{array}$ & $\mathrm{p}$ \\
\hline Laki-laki, n (\%) & $31(32)$ & $29(30)$ & $37(38)$ & 0,798 \\
\hline Umur (bulan), median (min-maks) & $91(7,1-213)$ & $69(2,9-205)$ & $66(5,5-200)$ & 0,097 \\
\hline Nyeri kepala, n (\%) & $23(41)$ & $12(21)$ & $24(32)$ & 0,062 \\
\hline Nyeri otot, n (\%) & $19(34)$ & $8(14)$ & $19(26)$ & 0,052 \\
\hline Nyeri perut, $\mathrm{n}(\%)$ & $6(11)$ & $21(36)$ & $39(53)$ & $<0,001^{*}$ \\
\hline Muntah, n (\%) & $3(5)$ & $4(7)$ & $10(14)$ & 0,218 \\
\hline Hepatomegali >2cm, n (\%) & $7(12)$ & $27(47)$ & $60(81)$ & $<0,001^{*}$ \\
\hline Kebocoran plasma, n (\%) & & & & $<0,001^{*}$ \\
\hline Edema palpebra & $1(2)$ & $23(40)$ & $39(53)$ & \\
\hline Efusi pleura & - & $45(78)$ & $72(97)$ & \\
\hline Ascites & - & $21(36)$ & $51(68)$ & \\
\hline \multicolumn{5}{|l|}{ Episode perdarahan, n (\%) } \\
\hline Petechie & $10(18)$ & $21(36)$ & $30(40)$ & $0,018^{*}$ \\
\hline Epistaksis / perdarahan gusi & $9(16)$ & $13(22)$ & $14(19)$ & 0,689 \\
\hline Perdarahan saluran cerna & - & $6(10)$ & $35(47)$ & $<0,001^{*}$ \\
\hline Letargi / akral dingin, $\mathrm{n}(\%)$ & $2(4)$ & $2(3)$ & $62(84)$ & $<0,001^{*}$ \\
\hline
\end{tabular}

${ }^{*} \mathrm{p}<0,05$, secara statistik bermakna 
Tabel 3. Profil laboratoris

\begin{tabular}{lcccc}
\hline Profil laboratoris & DD & DBD & SSD & Nilai p \\
& $56(30 \%)$ & $58(31 \%)$ & $74(39 \%)$ & \\
\hline Hematokrit \% (rerata \pm SD) & $40,0 \pm 3,7$ & $43,2 \pm 5,3$ & $46,2 \pm 4,5$ & $<0,001^{*}$ \\
Leukosit $(/ \mathrm{uL})$ & 3.690 & 4.255 & 4.385 & 0,227 \\
$\quad$ median $($ min-maks) & $(1.370-16.800)$ & $(1.490-13.820)$ & $(1.130-22.760)$ & \\
Trombosit hr ke-4 (/uL) & 113.000 & 67.500 & 48.500 & $<0,001^{*}$ \\
$\quad$ median (min-maks) & $(35.000-236.000)$ & $(4.000-270.000)$ & $(5.000-170.000)$ & \\
Trombosit hr ke-5 (/uL) & 78.000 & 37.000 & 20.500 & $<0,001^{*}$ \\
$\quad$ median (min-maks) & $(13.000-188.000)$ & $(400-121.000)$ & $(5.000-109.000)$ & \\
Trombosit terendah (/uL) & 66.500 & 29.000 & 18.000 & $<0,001^{*}$ \\
$\quad$ median (min-maks) & $(13.000-188.000)$ & $(400-92.000)$ & $(4.000-66.000)$ & \\
NS1 antigen dengue, n $(\%)$ & $14(25)$ & $11(19)$ & $7(10)$ & 0,747 \\
Ig M dengue, $\mathrm{n}(\%)$ & $35(63)$ & $41(71)$ & $55(74)$ & 0,975 \\
Ig G dengue, $\mathrm{n}(\%)$ & $23(41)$ & $35(60)$ & $53(72)$ & 0,046 \\
\hline
\end{tabular}

${ }^{*} \mathrm{p}<0,05$, secara statistik bermakna

Tabel 4. Analisis bivariat DBD dan SSD dibandingkan dengan DD

\begin{tabular}{|c|c|c|c|c|c|c|}
\hline Profil & OR & $\begin{array}{l}\text { DBD } \\
\text { IK95\% }\end{array}$ & Nilai-P & OR & $\begin{array}{c}\text { SSD } \\
\text { IK95\% }\end{array}$ & $\mathrm{p}$ \\
\hline Nyeri perut & 4,73 & $1,74-12,88$ & 0,001 & 9,29 & $3,55-24,30$ & $<0,001^{*}$ \\
\hline Hepatomegali $>2 \mathrm{~cm}$ & 6,10 & $2,37-15,69$ & $<0,001^{*}$ & 30 & $11,23-80,15$ & $<0,001^{*}$ \\
\hline Petekie & 2,61 & $1,10-6,22$ & $0,028^{*}$ & 3,14 & $1,37-7,17$ & $0,006^{*}$ \\
\hline Letargi / gelisah/ akral dingin & 0,96 & $0,13-7,09$ & 0,972 & 139,5 & $29,88-651,21$ & $<0,001^{*}$ \\
\hline Kebocoran plasma & 400,7 & $47,6-3370,8$ & $<0,001^{*}$ & 1.980 & $175-22400$ & $<0,001^{*}$ \\
\hline Hematokrit $>45 \%$ & 4,06 & $1,48-11,13$ & $0,004^{*}$ & 14,51 & $5,50-38,27$ & $<0,001^{*}$ \\
\hline $\begin{array}{l}\text { Trombosit } \leq 50.000 / \mathrm{uL} \\
\text { (hari ke- } 4 \text { ) }\end{array}$ & 11,2 & $2,45-51,21$ & $<0,001^{*}$ & 37,45 & $8,48-165,34$ & $<0,001^{*}$ \\
\hline $\begin{array}{l}\text { Trombosit } \leq 50.000 / \mathrm{uL} \\
\text { (hari ke-5) }\end{array}$ & 8,15 & $3,49-19$ & $<0,001^{*}$ & 30,25 & $11,44-80$ & $<0,001^{*}$ \\
\hline $\begin{array}{l}\text { Trombosit } \leq 50.000 / \mathrm{uL} \\
\text { (selama perawatan) }\end{array}$ & 14,34 & $5,61-36,67$ & $<0,001^{*}$ & 54,29 & $14,98-196,85$ & $<0,001^{*}$ \\
\hline
\end{tabular}

${ }^{*} \mathrm{p}<0,05$, secara statistik bermakna

Tabel 5. Analisis multivariat regresi logistik (DD dengan DBD dan SSD)

\begin{tabular}{lcccccccc}
\hline Karakteristik & Koefisien & S.E. & Wald & df & p & OR & \multicolumn{2}{c}{ IK95\% } \\
\cline { 6 - 9 } & & & & & & & Min & Maks \\
\hline Nyeri perut & 1,622 & 0,550 & 8,708 & 1 & $0,003^{*}$ & 5,06 & 1,72 & 14,87 \\
Hepatomegali $>2 \mathrm{~cm}$ & 2,024 & 0,497 & 16,608 & 1 & $<0,001^{*}$ & 7,57 & 2,86 & 20,02 \\
Hematokrit $>45 \%$ & 1,630 & 0,548 & 8,834 & 1 & $0,003^{*}$ & 5,10 & 1,74 & 14,95 \\
Trombosit $\leq 50.000 / \mathrm{uL}$ & 2,879 & 0,790 & 13,268 & 1 & $<0,001^{*}$ & 17,80 & 3,78 & 83,80 \\
Konstanta & $-1,193$ & 0,307 & 15,080 & 1 & $<0,001$ & 0,30 & 0,17 & 0,55 \\
\hline
\end{tabular}

${ }^{*} \mathrm{p}<0,05$, secara statistik bermakna 
95\%: 2,86;20,02), hematokrit >45\% (OR 5,10, IK $95 \%: 1,74 ; 14,95)$, dan angka trombosit $\leq 50.000 / \mathrm{uL}$ (OR 17,80, IK 95\%: 3,78;83,80) di fase defervescence merupakan variabel independen terjadinya infeksi dengue yang lebih berat (DBD dan SSD) (Tabel 5).

\section{Pembahasan}

Tiga persen anak usia 0-18 tahun di antara 188 dengan infeksi virus dengue meninggal. Angka kematian yang tinggi ini disebabkan karena RSUP Dr. Sardjito merupakan rumah sakit rujukan. Angka kematian ini lebih tinggi dibandingkan CFR nasional sebesar 0,90\% (Kemkes, 2014). Penelitian Pangaribuan $\mathrm{dkk}^{3}$ melaporkan manajemen cairan sebelum masuk RSUP Dr. Sardjito yang tidak adekuat, perdarahan mayor, dan syok berkepanjangan merupakan faktor prognosis kematian pada anak dengan SSD.

Penelitian kami mengidentifikasi adanya nyeri perut, hepatomegali $>2 \mathrm{~cm}$, kebocoran plasma, episode perdarahan, letargi/akral dingin, nilai hematokrit, dan angka trombosit yang rendah saat fase defervescence sebagai karakteristik yang membedakan di antara derajat keparahan infeksi dengue. Hasil penelitian kami konsisten dengan penelitian serupa sebelumnya di Thailand. Perbedaan terletak pada faktor usia dan angka leukosit karena disebabkan perbedaan demografi serta cara pengambilan sampel. ${ }^{7}$

Nyeri perut termasuk salah satu faktor risiko yang penting untuk memprediksi derajat keparahan infeksi dengue. Nyeri perut dapat disebabkan perdarahan saluran cerna, hepatomegali, ataupun karena hipoksia jaringan akibat suplai darah ke organ viseral kurang saat kondisi pre dan syok. ${ }^{8}$ Hepatomegali $>2 \mathrm{~cm}$ juga merupakan faktor risiko yang kuat, pembesaran hati merupakan respon normal dari infeksi dengue, tetapi hal ini lebih berhubungan dengan DBD dan SSD dibandingkan dengan DD. ${ }^{9}$ Adanya edema palpebra, efusi pleura atau ascites akibat dari kebocoran plasma juga merupakan faktor risiko penting pada DBD dan SSD. ${ }^{10}$

Muntah termasuk tanda bahaya penting dalam memprediksi risiko terjadinya dengue berat, tetapi tidak ditemukan dalam penelitian kami. Hal tersebut mungkin dikarenakan belum dilakukan pencatatan data rekam medis secara lengkap sebelumnya sehingga menjadi keterbatasan dalam penelitian ini.

Perdarahan mayor yang pada umumnya berasal dari saluran cerna, seperti hematemesis dan melena, merupakan manifestasi perdarahan berat tersering ditemukan. Penelitian kami dan sebelumnya mendukung perdarahan gastrointestinal yang merupakan faktor prognostik penting. ${ }^{10} \mathrm{Hal}$ tersebut berhubungan dengan penurunan jumlah trombosit pada infeksi dengue berat. Anak dengan SSD yang mengalami perdarahan mayor mempunyai prognosis meninggal delapan kali lebih besar atau 88\% lebih tinggi dibandingkan anak dengan SSD yang tidak mengalami perdarahan mayor. Trombosit yang turun terjadi karena dampak supresi sumsum tulang dan peningkatan destruksi trombosit oleh hepar dan limpa akibat respon imun. ${ }^{11,12}$ Angka trombosit $\leq 50.000 / \mathrm{uL}$ berhubungan dengan risiko perdarahan hebat. ${ }^{13}$

Hematokrit $>45 \%$ juga merupakan faktor prognosis derajat keparahan infeksi dengue, temuan tersebut serupa dengan penelitian sebelumnya. ${ }^{9,14}$ Vaskulopati pada infeksi dengue menyebabkan peningkatan permeabilitas kapiler, yang berujung pada hemokonsentrasi dan terjadinya syok. ${ }^{12}$ Penelitian sebelumnya melaporkan angka leukosit $<5.000 / u L$ yang merupakan faktor risiko terjadinya klinis infeksi dengue yang lebih berat, tetapi tidak ditemukan pada penelitian kami. ${ }^{10} \mathrm{Hal}$ tersebut dapat disebabkan karena data diambil saat fase defervescence saat suhu badan turun, sebagian besar pasien akan mengalami leukopenia akibat supresi sumsum tulang. ${ }^{15}$

Hasil penelitian kami menguatkan rekomendasi WHO mengenai dengue warning signs dalam memonitor tingkat keparahan penyakit. Sesuai dengan rekomendasi WHO 2009 dan 2011, penilaian warning signs seyogyanya dilakukan saat memasuki fase kritis/defervescence untuk mencegah terjadinya over-admission. Kelebihan penelitian kami adalah data diambil saat fase kritis/defervescence sehingga bermanfaat dalam triase untuk mengidentifikasi pasien yang membutuhkan observasi lebih lanjut di unit rawat inap. Namun demikian, penelitian kami juga memiliki keterbatasan karena data diambil secara retrospektif dari rekam medis.

\section{Kesimpulan}

Nyeri perut, hepatomegali $>2 \mathrm{~cm}$, hematokrit $>45 \%$ dan angka trombosit $\leq 50.000 / \mathrm{uL}$ pada fase defervescence merupakan faktor prognosis independen terjadinya infeksi dengue yang lebih berat (DBD dan SSD). 


\section{Daftar pustaka}

1. World Health Organization: Comprehensive guidelines for prevention and control of dengue and dengue haemorrhagic fever: revised and expanded edition. Geneva: World Health Organization; 2011.

2. Karyanti MR, Uiterwaal CSPM, Kusriastuti R, Hadinegoro SR, Rovers MM, Heesterbeek H, dkk. The changing incidence of dengue haemorrgahic fever in Indonesia : a 45-year registrybase analysis. BMC Infect Dis 2014;14:1-7

3. Pangaribuan A, Paryanto E, Safitri I. Faktor prognosis kematian sindrom syok dengue. Sari Pediatri 2014;15:332-40.

4. World Health Organization: Dengue guidelines for diagnosis, treatment, prevention and control. Geneva: World Health Organization; 2009.

5. Barniol J, Gaczkowski R, Barbato EV, Cunha RV, Salgado D, Martinez E, dkk. Usefulness and applicability of the revised dengue case classification by disease: multi-centre study in 18 countries. BMC Infect Dis 2011;11:106.

6. Kalayanarooj $S$ : Dengue classification : current $\mathrm{WHO}$ vs. the newly suggested classification for better clinical application? J Med Assoc Thai 2011,94:74-84.

7. Pongpan S, Wisitwong A, Tawichasri C, Patumanond J. Prognostic indicators for dengue infection severity. Int J Clin Pediatr 2013;2:12-8.
8. Junia J, Garna H, Setiabudi D. Clinical risk factors for dengue shock syndrome in children. Paediatr Indones 2007;47:7-11.

9. Shah GS, Islam S, Das BK. Clinical and laboratory profile of dengue infection in children. Kathmandu Univ Med J (KUMJ) 2006;4:40-3.

10. Gupta V, Yadav TP, Pandey RM, Singh A, Gupta M, Kanaujiya P, dkk. Risk factors of dengue shock syndrome in children. J Trop Pediatr 2011;57:451-6.

11. Soegijanto S, Budiyanto, Kartika, Taufik, Amor. Update management of dengue complication in pediatric. Ind J of Trop Infect Dis 2011; 2:1-11

12. Lei HY, Yeh TM, Liu HS, Lin YS, Chen SH, Liu CC. Immunopathogenesis of dengue virus infection. J Biomed Sci 2001;8:377-88.

13. Jr GDR, Torno LL. Association of leukocyte and thrombocyte counts as a predictor of bleeding outcomes among dengue patients. Philippine J Microbiol Infect Dis 2007;36:33-8.

14. Chacko B, Subramanian G. Clinical, laboratory and radiological parameters in children with dengue fever and predictive factors for dengue shock syndrome. J Trop Pediatr 2008;54:137-40.

15. Srichaikul T, Nimmannitya S. Haematology in dengue and dengue haemorrhagic fever. Baillieres Best Pract Res Clin Haematol 2000;13:261-76. 